\title{
IMAGENS DE UM CORPO POE(RÓ)TICO DIGITALIZADO
}

\author{
Adriana Carolina Hipólito de Assis ${ }^{*}$ \\ Universidade Federal de Santa Catarina
}

\begin{abstract}
Resumo: O presente trabalho tem por objetivo verificar como o corpo poético erotizado se evidencia nas imagens plásticas de algumas obras do poeta, tradutor e crítico literário brasileiro Décio Pignatari, assim como também colocar em debate a reintegração desse corpo desejante nas mídias a partir da crítica explicitada pelo poeta e ensaísta mexicano Octávio Paz na obra Conjunções e Disjunções (1979). Para tratar desse corpo amor(e)tizado nos deteremos como recorte de corpus de estudo a obra: Poesia Pois é Poesia, de Décio Pignatari (2004). Poéticas que expressam a marca concreta e põem em diálogo imagens advindas da tradução de um corpo digital que se estende (McLuhan), enquanto aparato comunicacional, midiático em confluência à concepção da arte como imagem digitalizada, como corpo sensório, tátil, erotizado. Presenças plásticas, corpóreas que refletem um rosto que sobrevive a própria imagem: um ícone concreto.
\end{abstract}

Palavras-chave: Poesia Concreta. Erotismo. Corpo Midiatizado. Corpo Poético.

\section{Homenagem e introdução...}

Sobrevivência das imagens de Décio Pignatari, poeta concreto que aqui jaz ausente, embora presente neste epitáfio ${ }^{1}$. A imortalidade dos concretos está na ritualização ${ }^{2}$ midiática das imagens que sobrevivem como extensão do corpo. Esse epitáfiohomenagem é nesse sentido uma forma de perpetuar a sobrevivência de um rosto memorialístico concreto. A composição tipográfica, afirma Décio Pignatari em Semiótica e Literatura (1987), mesmo em uma inscrição tumular é uma narrativa

\begin{tabular}{|c|}
\hline EPITÁFIO \\
\hline AQUI JAZ \\
DÉCIO PIGNATARI \\
MORTO \\
WOAIIO \\
EM LAGO EM LUA AOS \\
OITENTA E CINCO \\
ANOS \\
ORAI POR ELE! \\
(Carolina Assis) \\
\hline
\end{tabular}

Esta obra está licenciada sob uma Licença Creative Commons.

\footnotetext{
* Possui graduação em Língua e Literatura Portuguesa pela Pontifícia Universidade Católica de São Paulo (1995) e mestrado em Literatura e Crítica Literária pela Pontifícia Universidade Católica de São Paulo (2006). Atualmente é doutoranda em Literatura na UFSC. Tem experiência na área de Letras, com ênfase em Literatura, atuando principalmente nos seguintes temas: corpo, mitopoética, poesia concreta, espaço de ficção, hibridização, textualidade. E-mail: adricarolbas@gmail.com.

${ }^{1}$ Carolina Assis. Poema "Epitáfio" disponível no site: http://www.escrita.com.br/leitura.asp?Texto_ID=22892, acessado em 04-08-2014.

2 A "ritualização midiática" pressupõe a repetição da imagem em variadas mídias. Ritualizar, nesse sentido, é uma forma de manter e/ou fixar na memória a imagem nos meios comunicacionais.
} 
condensada ou um ideograma-poema com alto grau de iconização.

O presente trabalho tem por objetivo verificar como o corpo poético erotizadose evidencia nas imagens plásticas, do tradutor e crítico literário brasileiro, falecido em 2012, assim como também colocar em debate a reintegração desse corpo desejante nas mídias a partir da crítica explicitada pelo poeta e ensaísta mexicano Octávio Paz na obra Conjunções e Disjunções (1979).

Como recorte de corpus de estudo nos deteremos na obra: Poesia Pois é Poesia, poéticas que expressam a marca concreta e põem em diálogo imagens advindas da tradução de um corpo que se estende (MCLUHAN, 1977; 2000), enquanto aparato comunicacional, midiático em confluência a concepção da arte como imagem, como corpo sensório, tátil e erotizado.

\section{O corpo poético concreto como extensão digitalizada...}

Uma das vertentes atuais derivada da lógica edificada pelos concretos é a concepção do corpo comunicacional que se estende às mídias. Arquitetura que, obviamente, participa de uma teia e de um bojo teórico vasto e que tem início não só na compreensão de uma arte que se instala desde a afamada semana de 22 , mas também da projeção da palavra poética concebida como aparato técnico advindo desde os tipos móveis de Gutenberg (MCLUHAN, 1977), utilizados para a reprodução em série da palavra. Tipografia que só ganha status artístico, na medida em que projeta graficamente um corpo poético. A imagem gráfica se comporta de forma verbovocovisual, o que equivale à extensão de umcorpo comunicacional ou de um corpo-voz, de um corpo-olho, de um corpo-tátil plástico, performático, sensório que, uma vez dobrado (DELEUZE, 1991), reconstrói virtualmente no modo impresso, eletrônico ou cibernético um corpo poético. A Galáxia de Gutenberg, de Marshall McLuhan (1977) e Os Meios de Comunicação como Extensões do Homem, texto traduzido por Décio Pignatari (2000) se constituem, nesse sentido, como textos basilares para a compreensão da concepção da palavra digitalizada como extensão do corpo. A primeira expõe a crise e a fusão cultural resultante, primeiro do processo de alfabetização, e, depois do advento da palavra impressa. Mudança que possibilitou desenvolver

tudo que se costumava fazer com o próprio corpo, extensões ou prolongamentos desse corpo. A evolução de suas armas começa pelos dentes e punhos e termina com a bomba atômica. Indumentária e casas extensões dos mecanismos biológicos de controle de temperatura do corpo. A mobília substitui o acocorar-se e sentar-se no chão. Instrumentos mecânicos, lentes, televisão, telefones e livros que levam a voz através do tempo e do espaço constituem exemplos de extensões materiais. Dinheiro 
é meio de estender os benefícios e de armazenar trabalho. Nosso sistema de transportes faz agora o que costumávamos fazer com os pés e as costas. De fato, podemos tratar de todas as coisas materiais feitas pelo homem como extensões ou prolongamento do corpo. (MCLUHAN, 1977, p. 21-22).

Grande parte do que se observa nas poéticas contemporâneas advém desse processo ou da passagem da oralidade à grafia. Para McLuhan (1977) a oralidade apresenta, assim como a palavra impressa, mecanismos sensórios estendidos do corpo. A sociedade oral apresenta poéticas essencialmente audíveis, sendo a contra partida gráfica, abstrata da palavra: visual. Substituiu-se o ouvido pela visão, saímos de sociedade tribal, mágica, ritualística para uma destribalização tecnológica. Por isso Décio Pignatari enfatiza que toda a comunicação, sobretudo a arte contemporânea é visual, mascom extensões sensoriais de outros órgãos do corpo. Somos tocados sensorialmente pelas abstrações do olhar, o que nos permite a proliferação dos sentidos hápticos com o intuito de ritualizar o corpo nas mídias por meio de imagens, cenas, quadros ou partes do corpo.

Esse prolongamento do corpoestá presente também na obra Os Meios de Comunicação como Extensões do Homem. Nela a mensagem-poema se configura a partir da fusão ou da (con)fusão do homem com a mecanização da era industrial - na qual a "máquina transforma a Natureza em uma forma de arte" (MCLUHAN, 2000, p. 12) -, do entendimento da palavra como dígito, como ideograma capaz de condensar a mensagem poética em uma única capsula poética. A concepção ideogramática apontada por Haroldo de Campos em Ideograma, Lógica, Poesia e Linguagem (1994), possibilitou o intercâmbio imagético do oriente com o ocidente com sensorialidades corpóreas singulares. Tal perspectiva deriva do forte elo das poéticas concretas com os ideogramas. Cada ideograma é um desenho bastante concreto do contato do homem com a natureza ou com o corpo. "Por exemplo, o ideograma 'falar' é uma boca de onde saem duas palavras e uma chama” (CAMPOS, 1994, p. 115). Esse contato direto fenomenológico entre o signo e o objeto, mantém na palavra uma relação tribal, mítica. Nela a imagem apresenta qualidades táteis, tocamos os objetos e somos tocados por ele.

O poema abaixo contém no gesto da palavra o germe dessa concepção, são três palavras que explicitam a morte quixotesca no poema Dom Quimorte/3 Versões. O corte estendido da letra " $\mathrm{t}$ " remonta aos jogos medievais nos quais o cavaleiro andante abate, mata com a lança-palavra o adversário nos jogos de amor cortês. Esse gesto estético estendido da letra ritualiza, analogamente, mantém a forma gráfica dos ideogramas: 

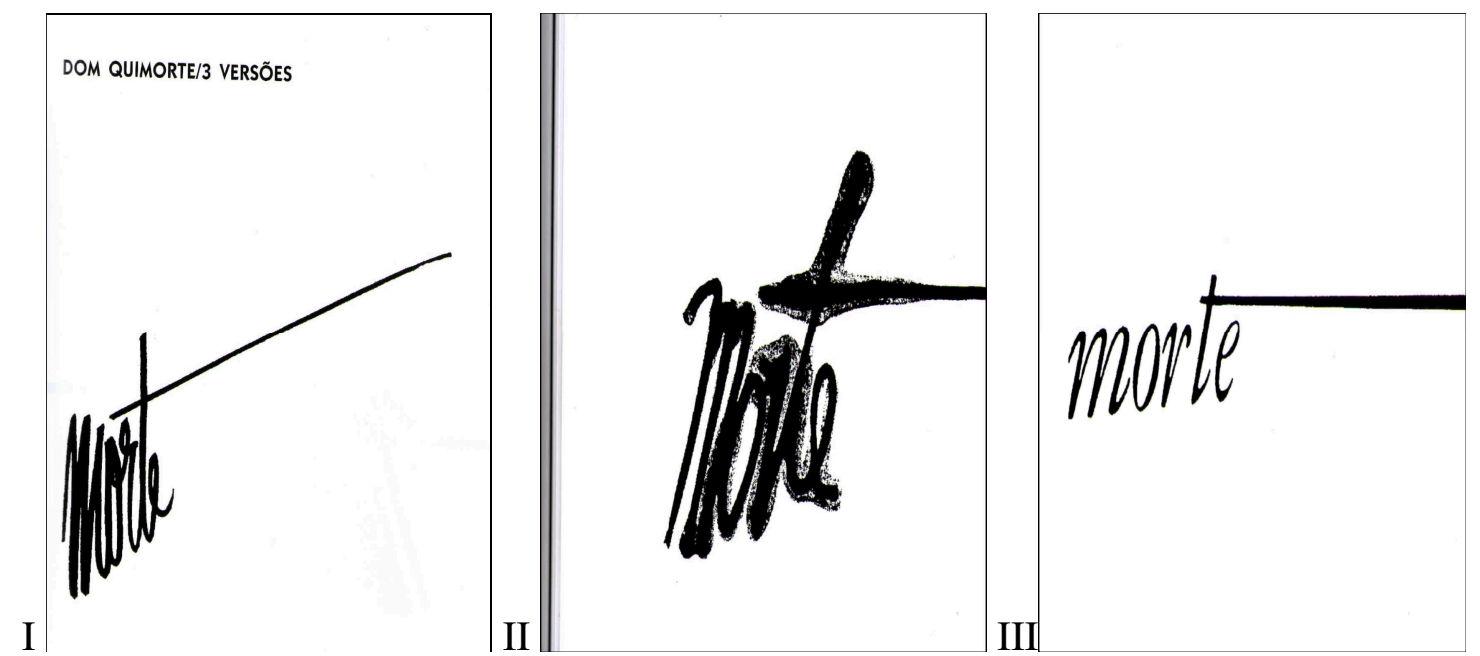

Fonte: Pignatari, Décio. Poesia Pois é Poesia. São Paulo: UNICAMP, 2004

A definição de dígito para os concretos está associadíssima ao caráter palpável do signo, sua concretude se dá a partir de duas linhas teóricas principais que perpassam por sua lógica. A primeira deriva de Roman Jakobson (1995, p. 130) na qual a função poética projeta o princípio de equivalência do eixo de seleção sobre o eixo de combinação primando, quando se trata de prosa, pela contiguidade do signo; e, pela similaridade, quando se trata de poesia. Afirma Samira Chalhub (1988) em Metalinguagem sobre o caráter palpável, concreto da mensagem poética em Jakobson que:

o aspecto sensível, concreto, palpável do signo é o que chamamos - sob a
denominação de Saussure - de significante, seja a sonoridade, seja a forma gráfico-
visual. O signo cria seu próprio referente no contexto da mensagem, cria o seu
sentido. A figura chamada paronomásia [...] na qual reina o "jogo de palavras" é a
relação íntima e indissociável entre som e sentido. Podemos qualificar um texto de
poético quando desvelamos, na sua organização, as equivalências de som e sentido -
é um dos trabalhos de construção do poetar. Quando amor/ e / humor/ aparecem em
proximidade física, estructural, revelando semelhanças significantes - /humor
contém amor/ - apesar da distancia de significado, essa semelhança sonora
acarretada pela associação do som revela que o significado também é similar. [...] A
função poética define-se também como exploradora das fontes analógicas dos
signos, ou seja, o que há de virtualidades, de potencial de semelhança entre as
estruturas signicas resultará numa recuperação do sensível do signo. (CHALHUB,
1988, p. 20)

Além de Samira Chalhub especialista em Jakobson/Lacan, e ex-orientanda de Décio Pignatari, há, ainda, outros estudos como os de Haroldo de Campos em Metalinguagem e Outras Metas (1992) e Ideograma, Lógica, Poesia e Linguagem (1994). Textos que também tangenciam pelasteorias concretas associando-as às teorias de Roman Jakobson. Nelas os desdobramentos metalinguísticos são observáveis pela iconização da forma poética. Afirma Haroldo de Campos: 
Numa tradução [...] não se traduz apenas o significado, traduz-se o próprio signo, ou seja, sua fisicalidade, sua materialidade mesma (propriedades sonoras, de imagética visual, enfim tudo aquilo que forma, segundo Charles Morris, a iconicidade do signo estético, entendido por signo icônico "que é de certa maneira similar àquilo que ele denota”) [...] (CAMPOS, 1992, p. 35).

As traduções feitas pelos irmãos Campos e Pignatari convergem, na esteira das "triduções" mallarmáicas, para "um prolongamento do objeto" (CAMPOS, 2010, p. 114), para o corpo. Isso contribuiu com a concepção digital contida nas teorias mcluhanianas e nas peirceanas, das quais os concretos fizeram uso. A iconização da palavra ou da arte é o objetivo primeiro de qualquer poética, afirmam os concretos, uma vez que estabelece uma relação intrínseca com o objeto, representando-o por traços de semelhança ou analogia, em uma relação triádica de primeiridade, secundidade e terceridade. Representamens ${ }^{4}$ que se associam a uma imagem, a um diagrama ou a uma metáfora, na qual a palavra poética é o objeto.

Das tricotomias peirceanas Décio Pignatari e os irmãos Campos se valeram da relação do ícone como uma qualidade primeira, uma metáfora capaz de apreender o objeto de modo concreto como hipoícone ${ }^{5}$. O hipoícone também está sujeito às tricotomias na relação com objeto, mas importa para esse grupo de poetas - que ao primarem pela qualidade do signo em primeiridade -, apreender em suas poéticas imagens que possibilitassem enxergar nas constelações mallarmáicas: dígitos, imagens condensadas de ideogramas ou de pictogramas; já as imagens poéticas mais diáticas, análogas em suas partes são consideradas diagramas, existem poemas belíssimos do grupo que são digramas como os poemas semióticos Invenção 4; agora, aquelas que apresentam alto grau de simbolização, são metáforas.

Para os concretos a modernidade expressa esse pontilhismo gráfico, imagético, analógico que possibilita a compreensão da ampliação e do deslocamento das partes do corpo do homem nas mídias. Assim como na palavra háuma iconização na relação de contiguidade e similaridade com o signo, na qual comparece como dígito ou como ideograma; as imagens do corpo também, na poética - a partir da lógica de extensão mcluhaniana -, tornam-se dígitos

\footnotetext{
3 "Triduções", expressão utilizada para designar a participação dos três poetas concretos em traduções: Décio Pignatari, Augusto e Haroldo de Campos.

${ }^{4}$ Segundo Charles Sanders Peirce em Semiótica, SP: Perspectiva: "um representamen, é aquilo que, sob certo aspecto ou modo, representa algo para alguém. Dirige-se a alguém, isto é, cria na mente dessa pessoa, um signo equivalente, ou talvez um signo mais desenvolvido. Ao signo assim criado denomino interpretante do primeiro signo. O signo representa alguma coisa, seu objeto. Representa esse objeto não em todos os seus aspectos, mas com referência a um tipo de ideia que eu, por vezes, denominei representamen" (1990, p. 46).

5 Os hipoícones segundo Peirce são: "qualquer imagem material, como uma pintura, que é grandemente convencionada em seu modo de representação; porém em si mesma, sem legenda ou rótulo, pode ser denominado hipoícone" (PEIRCE, 1990, p. 64).
} 
passando a ser a mensagem o involucro-corpo-pele-habitação-vestuário de uma geografia cultural.

A manifestação dessa fragmentação das partes do homem é própria da contemporaneidade, da relação que construímos com o tempo - com a velocidade informacional -, e da forma como a mensagem poéticafoi impregnada e, ao mesmo tempo, normatizada pela replicação das imagens do cânone artístico nas mídias, influenciou poéticas advindas das traduções feitas de Mallarmé (CAMPOS, 2010) em Un Coup De Dés, ou de James Joyce em Finnegans Wake (CAMPOS, 1986), e por infinitas outras obras, que possibilitaram a manifestação deu ma nova espacialidade gráfica, imagens que sobreviveram na memória cultural, e que comparecem nas transcriações concretas como na releitura de Pignatari dos idos de 1967, nas poéticas de Invenção. Nelas o corpo da palavra, uma vez estendido em dígitos concretiza um lance concreto da palavra Mallarmé, metonímias de uma grande metáfora constelar que comparece dentro dos círculos do poema na constituição do movimento, do gesto de jogaro dado:

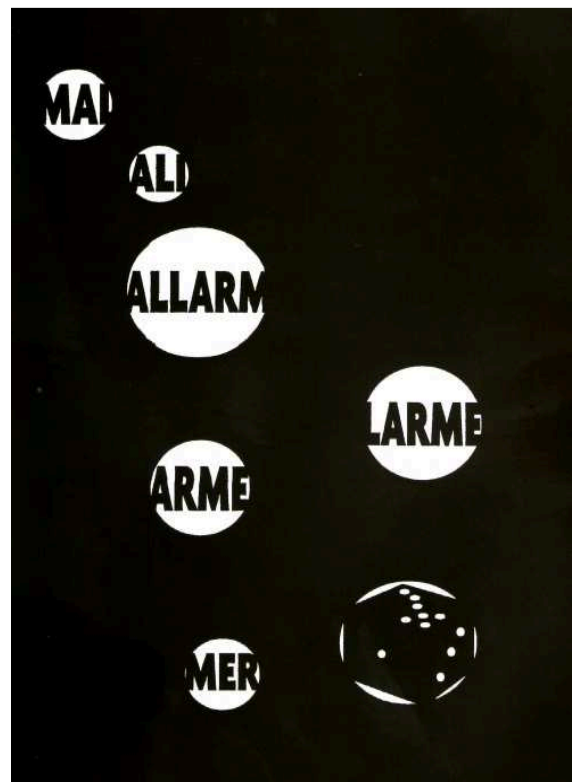

Fonte: Pignatari, Décio. Poesia Pois é Poesia. São Paulo: UNICAMP, 2004.

De outro modo essa fragmentação deriva de uma lógica benjaminiana com o "já clássico" A obra de arte no tempo de suas técnicas de reprodução (1983) texto que versa, sobretudo pela perda da aura, da autenticidade do objeto artístico único, artesanal para um sistema de arte industrial, demecanização e deautomação da informação, enfim de estandardização que privilegia uma arte utilitária presente no contexto da vida de todos que não leem a Fina flor do Lácio ouaaurada tradição, mas que está nos meios de comunicação de massa, na arquitetura, na moda, no design, na publicidade, na fotografia, no cinema, nos jornais, na TV. Arte cujo corpo (MCLUHAN, 2000) é fragmentado em partes - olho, audição, 
boca, pênis, vagina - estendido em virtualidades que extrapolam o campo do signo verbal, pois se inscrevem com uma forma poética hibridizada. Com isso há uma descontinuidade do corpo-fragmento para concretude ou iconização textual, espera-seuma continuidade uma linearidade advinda de uma aura-romance ou aura-poema, mas que se apresenta múltipla, pois reproduz a vertigem do fenômeno dos mass media, que, ao mesmo tempo, apresenta desdobramentos técnicos formais metalinguísticos ressaltados pela iconização do objeto artístico. Atualmente essa compreensão iniciada por McLuhan ganhou com os semioticistas peirceanos - na medida em que os meios tecnológicos se mutabilizaram -, novas leituras teóricas e críticas, nas quais o corpo é lido como prótese (SANTAELLA, 2004) es e caracteriza como uma extensão hibridizada, ou como um ciborgue que substitui ou amplifica as funções orgânicas. Teorias que não se separam da arquitetura elegida pelos concretos, principalmente as presentes nas obras teórico-críticas de Pignatari como: Semiótica e Literatura (1987) e Informação, Linguagem, Comunicação (1983), textos que enfatizam a imagem poética como ícone, uma iconização que não se deslocada dominante poética (PIGNATARI apud LIMA, 1983), acepção teorizada mais uma vez por Jakobson e acolhidas pelos concretos.

\section{Corpo poe(ró)tico...}

Uma das imagens que setornaramimortais de Décio Pignatarie que faz parte da série Ideogramas Verbais, presente em uma de suas melhores obras poéticas: Poesia Pois é Poesia (2004) são as duas palavras "homem" e "woman" cujo burilamento formal do design gráfico, possibilita a concepção ideogramática verbalizada, corpos que numa "relação amorosa" de línguas (português/Inglês) traduzem a androginia ${ }^{6}$ dos afetos. A "esfera de um" platônica (2000), um amor solar que une opostos (feminino e masculino). Poemas como esse deram a Pignatari a notoriedade de ser lembrado como o poeta que faz as palavras transarem concretamente:

\footnotetext{
${ }^{6}$ No livro do Banquete, de Platão, Aristófanes é umdos convivas do grande banquete oferecido por Agáton e discute, como todos os presentes, as faces de Eros. Para o comediante o mito do andrógino encarna a figura do amor, uma metáfora circular, uma esfera de um. Ele representa a eterna procura, o desejo de reencontrar a unidade dual. Esse mito também é bastante utilizado para a compreensão das questões de gênero (feminino $x$ masculino), e comparece também na fusão dos sexos como experiência mítica, no Ocidente Adão e Eva figuravam, antes da queda, como andróginos, depois que pecaram separam os sexos. Na literatura comumente aparece como um rito de passagem, um travestimento simbólico do ser.
} 


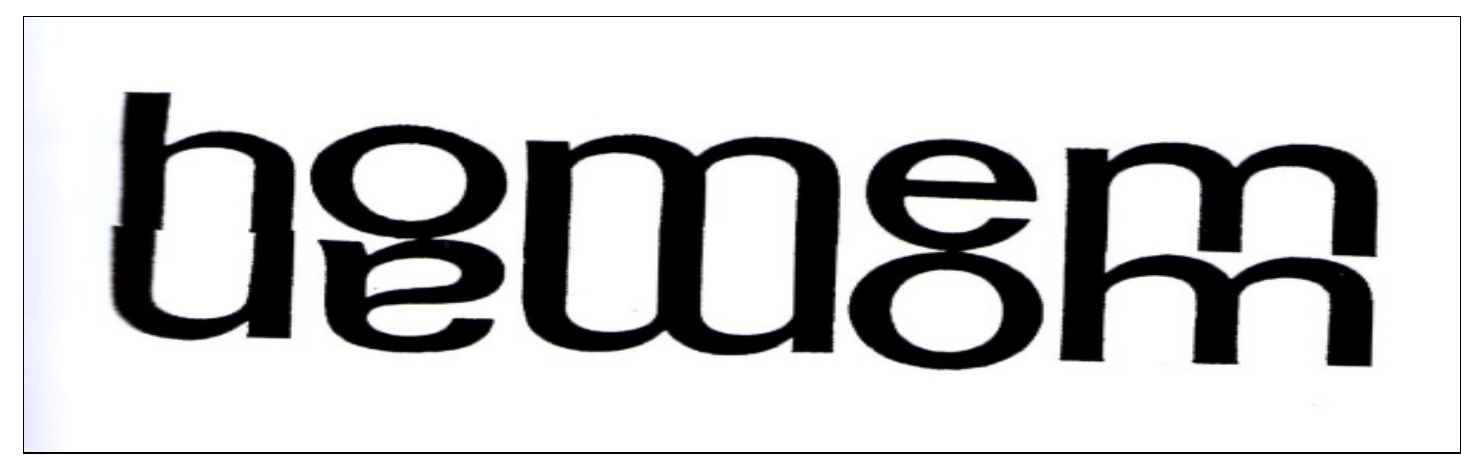

Fonte: Pignatari, Décio. Poesia Pois é Poesia. São Paulo: UNICAMP, 2004.

Do grupo ou da tríade concreta, Pignatari é o que se distinguiu por propor poéticas corpóreas, orgânicas, erotizadas compostas, em sua maioria, por apenas um dígito, além de apresentar, na prosa e em suas traduções, um acento com relação às idealizações de afetos, como as traduções de Dante Alighieri ou nos romances como Rosto da Memória e Panteros. Grande parte desse acento autoral advém das influências canônicas, da crítica, da vida acadêmica e das traduções que o grupo elegia. Dentre elas destaca-se a tradução de uma das obras de Octavio Paz, Transblanco (1986), poeta mexicano que viveu grande parte de sua vida na Índia e imprimiu em suas obras relações corpóreas/erotizadas baseadas em um barroquismo tântrico. Das influências acadêmicas, principalmente as do período em esteve na PUC-SP, Pignatari deteve-se em orientações que o aproximaram do erotismo batailliano em confluência à lógica lacaniana ${ }^{7}$. Autores que comparecem em suas obras conceitualmente traduzidos por metalinguagens, poéticas que observaremos no decorrer desse ensaio.

Afirma Octavio Paz em Conjunções e Disjunções (1979) que poesia e tantrismo ${ }^{8}$ se assemelham por experienciar concretamente o corpo. $\mathrm{O}$ oriente quer indiano tântrico, quer sino apresenta toda uma estética associada às práticas eratológicas, nas quais o prazer corpóreo se ramifica à estética. A alquimia erótica chinesa, afirma Paz, propõe a união de opostos num contínuo corpóreo. Essa continuidade procura ser concretamente sensação do corpo. "O princípio de "dois em um" - em simetria inversa ao que "um em dois" do arquétipo andrógino - inspira tanto a alquimia como a erótica mística em todo o mundo" (PAZ, 1979, p.

\footnotetext{
${ }^{7}$ A referência que destaco dessa influência acadêmica quanto ao erotismo em confluência à lógica lacaniana deriva do doutoramento na PUC-SP, de Samira Chalhub, nos idos de 1983: "Sob a (er)ótica da Linguagem", na época a autora era orientada de Décio Pignatari. Por certo que Pignatari já tinha uma linha erotizada em sua poética, mas parte de suas obras e críticas ganharam a partir deste contato um olhar lacaniano.

${ }^{8}$ Arte Hindu que tem por princípio a prática do Kama Sutra, filosofia comportamental que visa retirar a repressão do corpo, por isso o tantra é visto como sinônimo de libertação. Embora tenha uma ênfase espiritual, uma vez que se baseia em um corpo divino (Shiva, Shakti, Kali, Parvati), o tantra não "vê o corpo como um obstáculo, mas como um meio para o conhecimento", como forma de consciência do corpo. Ver mais no site disponível: http://pt.wikipedia.org/wiki/Tantra, acessado em 04-08-2013. E no livro: Kama Sutra - Mallanaga Vatsyana: segunda versão clássica de Richard Burton e F.F. Arbuthnot, traduzido por Dutra, Waltensir, RJ: Zahar, 2002.
}

Anu. Lit., Florianópolis, v. 19, n. 2, p. 169-187, 2014. ISSNe 2175-7917 
96). Nela o círculo, a geometria fonética da letra "o" do poema O Organismo, de Pignatari possibilita uma Gestalt (PERLS, 1997) erótica do oriente e do ocidente e que representa a eternidade, a imortalidade em um único dígito:

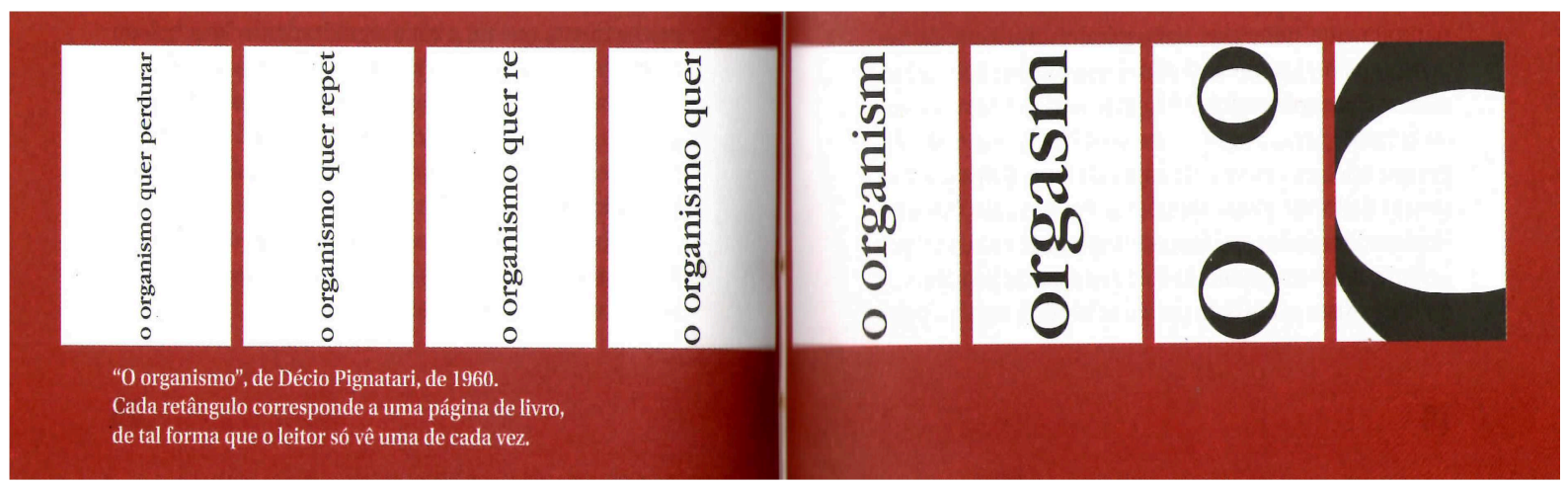

Fonte: Poema "Oorganismo", de Décio Pignatari. Cada parte é constituída por uma página completa de forma a visualizar uma de cada vez. Busquei, para melhor visualização, a junção gráfica de todas as partes na obra de Philadelpho Menezes. Roteiro de Leitura: Poesia Concreta e Visual. São Paulo: Ática; 1998, p. 76-77.

As poéticas concretas ganham corpo, com maior acuidade, na medida em que se encontra com as críticas do poeta e ensaísta Octavio Paz, principalmente aquelas cujos conceitos se relacionam ao "corpo" e ao "não corpo"; e, na poesia, como um signo em rotação desses mesmos corpos. Para Paz a relação com o "não corpo" se evidencia, principalmente, em laço social tanto para oriente quanto para o ocidente. A vida política, cultural, social, econômica, a virtude no trato da erotologia no oriente são extensões da virilidade do corpo, uma vez que possibilita o engendramento da vida, dos filhos. Logo é comum para os orientais preservar a energia do corpo feminino ou masculino como verdadeiros elixires da imortalidade. O sêmen e outros líquidos orgânicos ou o "tê" são energias que dão poder de transformação social/econômica/política a partir do corpo. Nesse sentido o "não corpo" estaria para aquilo que Georges Bataille (2004) trata como descontinuidade do ser (retomarei mais abaixo). Essa relação comparece como "não corpo" no oriente devido à conjunção de opostos (eliminação da dualidade: masculino x feminino; bem x mal) ao manter um elo corpóreo tribal, circular numa sociedade que ritualiza a natureza ao reintegrar o sêmen que absorve autorregulando a vida em conjunção.

Diferente da ótica ocidental que, para Paz, apresenta-se em disjunção, uma vez que não conciliam opostos e não ritualizam, na poética, o corpo. As duas posições (corpo e não corpo) expressam plasticamente reações frente à palavra-corpo-sêmen e/ou líquidos e 
excremento ${ }^{9}$. Em todas as sociedades ocidentais ou orientais o erotismo é visto de forma dupla, afirma Paz:

por um lado, é uma sublimação e uma transmutação imaginária da sexualidade servindo assim ao não-corpo; por outro é uma ritualização e uma atualização das imagens, servindo assim ao corpo. O rito corporal se refere ao não-corpo como se pode ver no tantrismo: a imagem erótica, como todos sabemos por experiência própria, se refere ao corpo. Na imagem o corpo perde sua realidade corpórea; no rito o não-corpo encarna. A relação entre os dois signos subsiste sempre, quer se trate de imagens tradicionais e ritos coletivos ou de fantasias individuais e jogos privados. Portanto, se a nova moral sexual carece efetivamente de referência ao não-corpo, isto deve ser interpretado como uma nostalgia da vida animal, uma renuncia da cultura humana e, consequentemente, do erotismo. [...] É uma moral: uma nova tentativa do não-corpo de deslizar sobre o corpo, desagregar sua imagem e convertêla em realidade abstrata. (PAZ, 1979, p. 113)

Para Paz houve uma passagem da religião à estética e nela, uma desencarnação do corpo quese estendeu às imagens, aos símbolos, aos ritos na relação com arte. No ocidente há uma relação desejante de dominação e de conversão de raízes teológicas. "A sociedade contemporânea deixou de ser cristã, mas suas paixões são as do cristianismo. Apesar de nossa ciência e de nossa técnica não serem religiosas, possuem uma índole cristã [...]” (PAZ, 1979, p. 105). Essa relação desejante repropõe uma ascese platônica ${ }^{10}$. Um êxtase que num contínuo, em androginia de afetos, se separam em disjunção, na descontinuidade dos seres como afirma G. Bataille (2004). O “não corpo" e o "corpo" comparecem disjuntivos no ocidente, pois embora haja união, sempre será um eu para um tu não corporificado. Somente em momentos de intenso prazer estético, de êxtase epifânico (SÁ, 1979) o ocidente se corporifica, isto é, os corpos se tocam. As poéticas que idealizam afetos preservam o corpo para manifestar-se num êxtase de "não corpo" como uma reserva oculta do sêmen-gozo, mas que se eleva epifanicamente em continuidade do ser. O "coitus reservatus" ${ }^{11}$ ", sobretudo as transcriações de Pignatari como no fragmento a seguir de Dante Alighieri percebe-se essa lógica:

\footnotetext{
${ }^{9}$ Embora Octavio Paz faça uma crítica ao Ocidente quanto ao não corpo, existe associações aproximativas com as teorias de G. Bataille (2004), que são essencialmente ocidentais, no que tange às substâncias que "evacuam dejeções" (BATAILLE, 2004, p. 88) e que se relacionam ao desejo, matérias que causam horror, náusea misturado à atração.

${ }^{10} \mathrm{O}$ termo ascese refere-se à renúncia do prazer ou satisfação sexual como o celibato, o jejum e alguns ritos como as escoriações no corpo feitas para matar o desejo da carne. Segundo o idealismo platônico, no qual a palavra ascese se assenta ou apresenta uma raiz conceitual, serve para aproximar o asceta à realidade espiritual $\mathrm{e}$ idealizante, o asceta desliga-se da materialidade do corpo visando ao espírito.

${ }^{11}$ Coitus reservatus - termo utilizado na obra de Octavio Paz em Conjunções Disjunções e designa uma das práticas sexuais do Tao, na qual se reserva a ejaculação, ou se posterga o gozo. Todos os textos corteses e românticos têm por característica a idealização dos afetos, acercamo-nos desse sentido ao observa que as obras de Décio Pignatari, sobretudo nas transcriações feitas pelo poeta/tradutor idealizam os afetos, não há coito.
} 
Assim que retornei, pus-me à procura da mulher que o meu senhor havia mencionado no caminho dos suspiros: para ser breve, devo dizer que, em pouco tempo, tão bem prestou-se de meu escudo, que muita gente começou afazer comentários que ultrapassavam os termos da educação - o que muito me pesava. Por esta razão, em função dessa excessiva maledicência, que parecia querer me atingir de modo infamante, a mais que gentil, destruidora de todos os vícios e rainha das virtudes, passando por mim, negou-me o docecumprimento, no qual eu depositava toda a minha esperança de salvação [...] (PIGNATARI, 2006, p. 28).

Há uma presença hermética desse desejo idealizante nas poéticas de Pignatari que aparecem, geralmente, dentro de um rococó barroco gráficoou em um ponto qualquer se manifesta de forma condensada e/ou fragmentada. O "corpus reservatus ${ }^{12}$ " manifesta-se poeticamente na sensorialidade, no movimento do corpo da palavra " $u m$ movimento", observe que a letra "u" esta separada graficamente da " $m$ ":

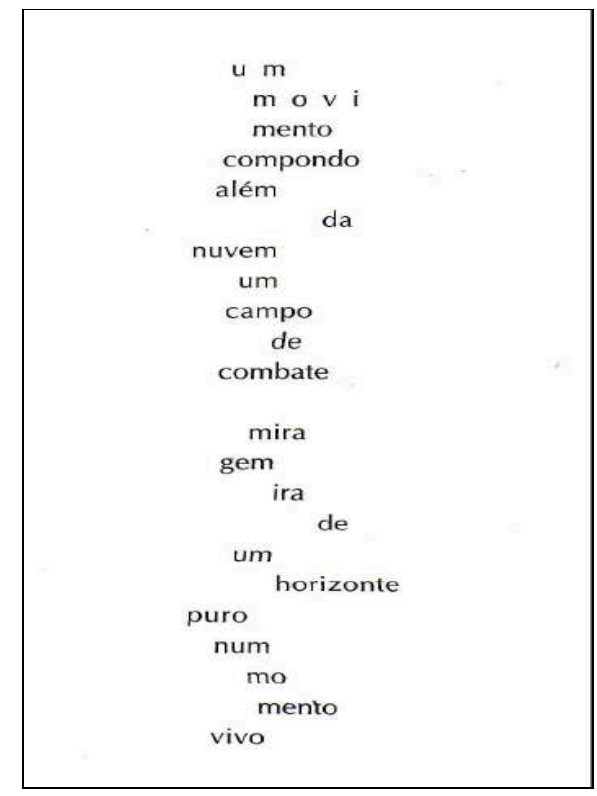

Fonte: Pignatari, Décio. Poesia Pois é Poesia. São Paulo: UNICAMP, 2004.

Embora saibamos que o corpo compareça como forma imaginária, principalmente na passagem explicitada acima de Dante Alighieri (do erotismo religioso à estética), o ensaísta verifica a falência da arte contemporânea ao não fornecer uma imagem do corpo para nos identificarmos. A solução para essa carência de corpo, afirma o ensaísta, seria uma missão destinada aos modistas e aos publicitários para celebrarem, nas mídias, a imagem de um corpo atual. "Nossa época é crítica: desfez a antiga imagem do mundo e não criou outra. Por isso não temos corpo." (PAZ, 1979, p. 122), houve, segundo o autor, uma "desencarnação": o equivalente a fragmentação do corpo poético a partir de Mallarmé, que não nos corporificou diante da grande rede comunicacional e poética.

${ }^{12}$ Transmutamos o sentido para corpus reservatus como reserva de um corpo palpável para ficar com um idealizante. 
O poema a seguir apresenta parte dessa missão ao dar um corpo desejante para nosso tempo, um poema que pode ser lido em várias posições erotizadas. Um prazer degustativo, sensório de "caviar", na palavra, posições que num cruzamento, se repetem ritmicamente nas palavras "prazer" e "porvir", na ambiguidade característica das poéticas barrocas, nas quais "prazer" e "porvir" apresentam dois tempos que ora se postergam em um "porvir", ora se presentifica em um "contemporaneizar". A proposta de um tempo sincrônico ${ }^{13}$, simultâneo, cujo prazer se articula, se conecta pela presença doartigo " $o$ " que repropõe o "torpor" como êxtase vertiginoso da contemporaneidade.

\section{caviar o prazer \\ prazer o porvir \\ porvir o torpor \\ contemporalizar}

Fonte: Pignatari, Décio. Poesia Pois é Poesia. São Paulo: UNICAMP, 2004, p. 146.

A forma do corpo poético dos concretos é ideogramática ${ }^{14}$, logo não há fragmentação em disjunção. As imagens do desejo, condensam, reconstroem o corpo, em um mesmo em dígito. Há uma dança de sobreposição do desejo que é barroca, que é sinuosa, na qual secome prazerosamente a atualidade. Os excessos nas poéticas de Pignatari são canibalísticos. O desejo ingerido em “caviar" ritualiza simbolicamente o alimento poético, a substância

\footnotetext{
${ }^{13}$ Existem duas formas de abordagem temporal do objeto artístico: o diacrônico, essencialmente histórico, contextual e o sincrônico caracterizado por buscar na simultaneidade temporal (diacrônica e sincrônica) um ponto de vista estético atual com dominante poética e não historiográfica. Ver mais em A Arte do Horizonte do Provável, de Haroldo de Campos, SP: Perspectiva, 1977, além do clássico Linguística e Comunicação, de Roman Jakobson. SP: Cultrix, 1995.

${ }^{14}$ Existem infinitas bibliografias acerca dos ideogramas com traduções feitas, inclusive, por Pignatari e, principalmente por Haroldo de Campos e Augusto de Campos. Obras que possibilitaram homenagens a Haroldo de Campos no Japão por transpor às suas obras o princípio ideogramático. Segundo Haroldo de Campos o ideograma apresenta um "elemento visual na poesia japonesa como algo que lhe é intrínseco [...] uma estrutura kanji, o ideograma chinês que os japoneses importaram [...] evoluiu de uma fase pictográfica (desenho do objeto) para uma extremamente sintética e estilizada, é, em si mesmo, uma verdadeira metáfora gráfica, tanto mais complexa quanto mais "abstratas" as ideias a veicular [...]" (CAMPOS, 1977, p. 63).
} 
afrodisíaca que repropõe a alquimia, a transmutação, suprimindo o dualismo (corpo x não corpo) na conjunção pela iconização do signo.

As poéticas de Pignatari ganham corpo também quando as confrontamos com os estudos de Georges Bataille (2004). Grande parte dos estudos acerca do erotismo proposto por Baitalle deriva da obsessão da adolescência por questões religiosas, por isso sua envergadura teórica se assenta na história da religião, na antropologia, na biologia e na psicanálise lacaniana. Importa para esse ensaio alguns aspectos acerca dos conceitos sobre continuidade e descontinuidade na relação com o corpo, além, é claro, de estabelecer diálogo com as teorias de Octavio Paz em concomitância às poéticas de Décio Pignatari e a concepção de dígito.

A relação com o erotismo em Bataille (BATAILLE, 2004, p. 21) se define "pela independência do gozo erótico e da reprodução como fim, o sentido fundamental da reprodução não deixa de ser a chave do erotismo". Nesse sentido o erotismo põe em jogo dois seres descontínuos, isto é, entre um ser e outro há uma descontinuidade, uma relação entre os corpos. Mas toda descontinuidade do ser perpassa por uma continuidade, pela morte dessa descontinuidade à continuidade. Para explicar essa relação, Bataille, faz uso de conceitos correlacionados à biologia. Na reprodução celular assexuada dois núcleos formados tornam-se, em um ponto, "um”, uma vez que um deles morre. Nos seres sexuados essa relação com a biologia do corpo não é tão distinta: espermatozoides e óvulo quando separados são descontínuos, unidos são contínuos. Na fusão celular há sobrevivência, embora haja morte daquilo que excede (outros espermatozoides). O novo ser é descontínuo, uma metáfora de alteridade em relação ao Pai. Metáfora que pode ser compreendida poeticamente, à medida que todo texto é unidade mínima de significação que uma vez germinada torna-se outro texto num processo de "semiose ilimitada", ou de constelações mallarmáicas que possibilitam a construção em rede de poemas, ou, ainda, de "transcriações": traduções criativas, erotizadas, desejantes como as que Décio Pignatari e os irmãos Campos.

Bataille afirma que há uma "nostalgia" com relação à continuidade do ser, algo muito próximo do mito da Androginia, conceito que já fizemos referência anteriormente. Essa sensação nostálgica talvez, para Bataille, seja uma relação temporal com o corpo, da memória do corpo que deseja duração, continuidade do ser na perpetuaçãodo gozo. Logo há uma passagem sensória do corpo que retorna à origem, talvez, ao útero - ao dois em um -, ou, ao Pai criando assim uma angústia de influência por uma continuidade. Essa "nostalgia" da

\footnotetext{
${ }^{15}$ O processo de semiose descrito por C. S. Peirce e reinterpretado por Lucia Santaella, em A teoria geral dos Signos Semiose e Autogeração, resulta da ação do signo "que é a ação de ser interpretado, apresenta com perfeição o movimento autogerativo, pois ser interpretado é gerar outro signo que gerará outro, e assim infinitamente" (SANTAELLA, 1995, p. 11).
} 
continuidade é também uma obsessão religiosano sentido de religar-se ao sagrado. Afirma Bataille que

uma procura sistemática de uma continuidade do ser para além do mundo imediato requer esforço essencialmente religioso; em sua forma familiar no Ocidente, o erotismo se confunde com a busca, exatamente com o amor de Deus, mas o Oriente prossegue uma busca similar sem necessariamente colocar em jogo a representação de um Deus. (BATAILLE, 2004, p. 27)

Em Lacan (2005), na esteira do Totem e Tabu, de Sigmund Freud (1974), há uma aproximação desse retorno nostálgico como um "Deus-sintoma", no qual se consagra um Deus que não existe - que, aliás, nunca teve corpo -, mas que se normatiza enquanto desejo resultante do amor do Pai. Logo, Deus existe enquanto Pai. Mas, se deseja o quê? Uma ascese platônica, um alto celestial inalcançável ou um baixo celestial de uma chaga/ferida desejante de um filho/Jesus? Mas é com esse Pai que o ocidente se assenta e se torna descontínuo, embora deseje até às vísceras - enquanto causa do desejo - a continuidade de um Pai. Para o oriente, apesardas "Pálpebras de Buda", no Seminário, livro 10 (LACAN, 2005) estarem semicerradas e de todas as esculturas representarem a mesma imagem, como afirma Lacan, Deus não existe, mas, o Buda tem corpo, um corpo cujas pálpebras criam uma ambiguidade poética/imaginária com sua imagem, uma vez que não se sabe se Buda olha para dentro ou para fora. A ambiguidade do olhar e da feição impossibilita, também, saber se o corpo é masculino ou feminino, sua imagem é andrógina, um corpo que retira a dualidade, a polarização do masculino e do feminino, do sim e do não. Mas como desejar, se seu olhar pretende mostrar o não desejo, pois tudo é ilusão? Lacan afirma que "se existe um objeto de teu desejo, ele não é outro senão tu mesmo" (LACAN, 2005, p. 245). O desejo de uma conjunção em disjunção, pois Buda reafirma o próprio ser em detrimento do outro. Lacan enfatiza que o "desejo sempre continua, em última instância, a ser desejo do corpo do Outro, e nada além de [seu] corpo.” (LACAN, 2005, p. 237). O Buda pretende um estado de equilíbrio. O que não deixa de ser um Pai corporizado que também remete a uma ascese, a um desejo em êxtase "nirvânico" a ser alcançado.

O que nos possibilita devaneios fálicos com o sexo também. A concepção de falo para Lacan é andrógina em Deus e o Gozo d'A Mulher (LACAN, 1985), nele o masculino e feminino se conjugam, há um "a mais" feminino que cooparticipa do masculino. Existe falo para homens e mulheres. Na literatura a exemplo desse gozo conjuntivo está o amor cortês: idealizante e mediado por um falo: os dois sexos se conjugam noamor sagrado, inalcançável. Assim, arremata Lacan, que a causa do desejo, o objeto "a", só existe enquanto ato logo o ato amoroso cortês ou divino (para Buda ou para Madre/Jesus) "é poesia." (LACAN, 1985, p. 
98). Portanto a imagem das "pálpebras de Buda", para o oriente; ou a imagem da Madre Tereza, de Bataille, ou de Jesus, como imagens estruturais de um corpo para o ocidente se equiparam enquanto sagrado por representarem uma divindade que pode ser masculina ou feminina. Bataille compreende essa experiência poética na continuidade, numa estética erotizada:

A poesia leva ao mesmo ponto que cada forma do erotismo, à indistinção, à confusão dos objetos distintos. Ela nos leva à eternidade, ela nos leva à morte, à continuidade: a poesia é a eternidade. É o mar que estrada junto com o sol, unidade. (BATAILLE, 2004, p. 40)

Essa experiência poética para Bataille está atrelada à concepção da interioridade, da interdição e da transgressão do corpo desejante. O trato da interioridade, na poética, estaria para a imanência do objeto artístico, para a materialidade da palavra expressa no imaginário. O corpo de dentro (das Pálpebras de Buda ou de Deus), embora se constitua enquanto “mistério invisível” (CHAUÍ, 1981) aparece de modo palpável em sinuosidades barrocas, em sinestesias da forma, em poesia concreta. A interioridade manifesta-se como extensões do corpo, uma associação que podemos inferir com a lógica de McLuhan (1977; 2000). Prolongamentos internos que saem para a poética nas imagens midiáticas e/ou poéticas nas cenas, nos quadros advindos dos sonhos, dos desejos, das fantasias inconscientes, ou da mais valia do comércio, do desejo ritualizado econômica/socialmente com o intuito de replicar uma continuidade do êxtase de possuir, sacrificar, matar o desejo.

O segredo do erotismo para Bataille está no esforço de violar, transgredir as interdições - tabus sociais, relações sagradas como a noção de pecado que em sua maioria são descontínuas, com o intuito de atingir a continuidade do ser. Assim o campo do erotismo, afora a questão corpo/célula, é violência. Daí buscar além do erotismo sagrado ${ }^{16}$, o erotismo profano. Ambos procuram o limiar da violência, o êxtase epifânico extremamente corpóreo como uma forma de ritualizar uma estética que perdure um instante de continuidade do ser, uma conjunção que possibilite o não dualismo do corpo, a digitalização da forma poética, que uma vez mallarmeitizada ou fragmentada, "rasga" o corpo pela morte/desmembramento das partes nas mídias, na descontinuidade do ser, no “não corpo” de Paz.

Bataille expõe um corpo erótico ocidental como uma equivalência aparente à conjunção de Octavio Paz. Essa equivalência se dá por conceber o erotismo dentro de uma

\footnotetext{
${ }^{16} \mathrm{O}$ erotismo sagrado para Bataille esta associado às interdições ou limitações, embora o erotismo seja sinônimo de festa, ainda assim, é uma interdição: uma festa de soberanos e deuses, de adoração aos santos, de fascínio sagrado transfigurado em êxtase. Assim o erotismo sagrado é transgredido para uma profanidade para um canibalismo antropofágico de festa de comer a carne, que também é interdição rasgada por uma transgressão.
} 
lógica essencialmente cristã, com mitos que reintegram eroticamente o corpo de cristo/madre, embora, paradoxalmente, faça referência ao oriente conforme apontamos acima. Mas, para o ensaísta mexicano há uma diferença na relação com a poética oriental que o ocidente perdeu. O nó (aparente?) estaria justamente na concepção disjuntiva presente no ocidente. Embora a relação de descontinuidade seja importante enquanto alteridade poética, não há conjunção para o ensaísta mexicano no ocidente, houve um desmembramento sem a reconstituição de uma imagem corpórea capaz de manter a continuidade como forma desejante. Seria uma perda da referencialidade, de encontro identitário entre a obra de arte e o homem? Talvez o que Octavio Paz aponte seja a falta de um arquétipo, de um mito fundante de um corpo, pois não somos mais "isso" ou "aquilo", logo somos mistura sem consciência de um corpo!? Buscamos a disjunção polarizadora e não a conjunção integradora? Ou o ocidente ainda não soube passar da oralidade à escrita, não soube estender o corpo enquanto aparato tecnológico, comunicacional como observamos em McLuhan, no sentido de ajustar a percepção para um dígito que possa prolongar uma continuidade para tocar visualmente, na palavra, no corpo grafo, uma visualidade tátil, abstrata e não tão tribal/oral/mítica? É preciso que a obra nos toque, nos afete e que fale do próprio corpo, é preciso que a palavra ganhe corpo poético. Esse corpo poético só se manifesta para outro quando se tem consciência estética do objeto. Afirma Paz que a poesia

\footnotetext{
coloca o homem fora de si e, simultaneamente o faz regressar ao ser original: volta-o para si. O homem é sua imagem: ele mesmo e aquele outro. Através da frase que é ritmo, que é imagem, o homem - esse perpétuo chegar a ser - é. A poesia é entrar no ser. (PAZ, 1990, p. 50).
}

A resposta para esse impasse estaria na forma crítica e poética edificada pelos concretos em consonância às concepções semióticas utilizada como suporte teórico-prático, na qual buscaram a continuidade observada em Bataille ou a conjunção oriental de Paz, por meio de formas ideogramáticas, de signos em primeiridade, ícones em que desejamos enquanto obra integradora, miscigenadas e/ou hibridizadas na relação ocidente x oriente. Não se trata só de simbolizar ou de alegorizar o objeto artístico com signo em secundidade e terceiridade, é preciso, nessa construção, reintegrar ocorpo em ícone.

Para que o corpo poético nos toque é preciso que a obra de arte, como afirma DidiHuberman (2010), haja uma troca de olhares. Para Lacan, na esteira de M. Ponty "a percepção não esta em mim, ela está sobre os objetos que apreende. E, no entanto, percebo o mundo numa percepção que parece depender da imanência do vejo-me ver-me" (LACAN, 1998, p. 81). É preciso uma apalpação do olhar, da tatilizaçãoda visão, do tocar a arte. 


\section{Referências}

ASSIS, Carolina. Epitáfio. Disponível no site: http://www.escrita.com.br/leitura.asp?Texto_ID=22892, acessado em 04-08-2014.

BATAILLE, Georges. O Erotismo. São Paulo: Arx, 2004.

BENJAMIN, Walter; et al. A obra de arte no tempo de suas técnicas de reprodução. In. . Textos escolhidos: Os Pensadores. São Paulo: Abril Cultural, 1983.

CAMPOS, Augusto. Poesia, antipoesia, antropofagia. São Paulo: Cortez \& Moraes, 1978.

CAMPOS, Augusto; CAMPOS, Haroldo; PIGNATARI, Décio. Mallarmé. São Paulo: Perspectiva, 2010.

CAMPOS, Augusto; CAMPOS, Haroldo. Panorama de Finnegans Wake. 3.ed. São Paulo: Perspectiva, 1986.

CAMPOS, Haroldo. Metalinguagem \& Outras Metas. São Paulo: Perspectiva, 1992. A Arte no Horizonte do Provável e outros ensaios. São Paulo: Perspectiva, 1977. Ideograma - Lógica, Poesia, Linguagem. São Paulo: EDUSP, 1994.

; et al. Teoria da Poesia Concreta - Textos críticos e manifestos 1950-1960. São Paulo: Livraria Duas Cidades, 1975.

CHALHUB, SAMIRA. A Metalinguagem. São Paulo: Ática, 1988.

CHAUÍ, Marilena de Souza. Da realidade sem mistérios ao mistério do mundo. (Espinosa, Voltaire, Merleau-Ponty). 2.ed. São Paulo: Brasiliense, 1981.

CHEMAMA, Roland. Dicionário de Psicanálise Larousse. Porto Alegre: Artes Médicas, 1995.

DELEUZE, Gilles. A Dobra Leibniz e o Barroco. São Paulo: Papirus, 1991.

DIDI-HUBERMAN, Georges. O que vemos, o que nos olha. São Paulo: Editora 34, 2010.

FREUD, Sigmund. Totem e Tabu e outros trabalhos. V1. XIII. Rio de Janeiro: Imago, 1974.

JAKOBSON, Roman. Linguística e Comunicação. São Paulo: Citrix, 1995.

A Dominante. In: LIMA, Luiz Costa (Org.) Teoria da Literatura e suas fontes. Rio de Janeiro: Francisco Alves, 1983.

LACAN, Jacques. O Seminário, livro 10: A Angústia. Rio de Janeiro: Jorge Zahar, 2005. O Seminário, livro 11: os quatro conceitos fundamentais da psicanálise. Rio de Janeiro: Jorge Zahar, 1998. O Seminário, livro 20: Mais, ainda. Rio de Janeiro: Jorge Zahar, 1985. 
MCLUHAN, Marshall. Os meios de comunicação como extensões do homem. Trad. de Décio Pignatari. São Paulo: Cultrix, 2000.

A Galáxia de Gutenberg. A formação do homem tipográfico. São Paulo: Editora Nacional, 1977.

MENEZES, Philadelpho. Roteiro de Leitura: poesia concreta e visual. São Paulo: Ática, 1998. PAZ, Octavio. Signos em Rotação. São Paulo: Perspectiva, 1990. Conjunções e Disjunções. São Paulo: Perspectiva, 1979.

. Transblanco: em torno a Blanco de Octavio Paz. Trad. Haroldo de Campos. Rio de Janeiro: Guanabara Koogan, 1986.

PEIRCE, Charles S. Semiótica. São Paulo: Perspectiva, 1990.

PERLS, Frederick Salomon et al. Verbalização e poesia. In: Gestalt-terapia. São Paulo: Summus, 1997.

PIGNATARI, Décio. Semiótica \& Literatura. São Paulo: Cultrix, 1987. Informação, linguagem e Comunicação. São Paulo: Cultrix, 1983. . O que é comunicação poética. 2.ed., São Paulo: Brasiliense, 1989. . O retrato do amor quando jovem: Dante, Shakespeare, Sheridan, Gouthe. São Paulo: Cia das Letras, 2006. . Poesia Pois É Poesia. São Paulo: Ateliê/UNICAMP, 2004.

PINHEIRO, Amálio. Aquém da Identidade e da Oposição - formas na cultura mestiça. Piracicaba/SP: UNIMEP, 1994.

SÁ, Olga. A escritura de Clarice Lispector. Petrópolis: Vozes; Lorena: FATEA, 1979.

SANTAELlA, Lucia. A teoria geral dos Signos, semiose e autogeração. São Paulo: Ática, 1995.

Corpo e Comunicação - sintoma da cultura. São Paulo: Paulus, 2004.

VATSYAYANA, Mallanga. Kama Sutra da versão clássica de Richard Burton. Rio de Janeiro: Jorge Zahar, 2002.

Tantra: disponível no site: http://pt.wikipedia.org/wiki/tantra, acessado em 04-08-2013.

[Recebido em janeiro de 2014 e aceito para publicação em abril de 2014]

\section{Images of a poe(ro)tic body scanned}

Abstract: This study aims to determine how the poetic eroticized body is evident in the visual images of some works of the poet, translator and literary critic Brazilian Décio Pignatari, as 
well as put on the reintegration of this debate in the media desiring body from the critical explained by the Mexican poet and essayist Octávio Paz is work Conjunções e Disjunções (1979). To address this body lov(e)rotic as cut corpus study of the work: Poesia Pois é Poesia, of Décio Pignatari (2004). Poetry expressing the brand and put in concrete dialogue resulting images of translating a digital body that extends (McLuhan) while communication apparatus, media convergence in the conception of art as scanned image, such as sensory, tactile, eroticized body. Attendance plastic, tangible reflecting a face that survives own image: a concrete icon.

Keywords: Concrete Poetry. Eroticism. Poetic body. Mediatized body.

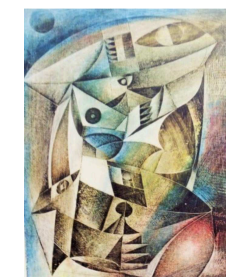

